\title{
Motives Influencing Facebook Usage By Students And Its Relationship With Facebook Addiction Disorder
}

\author{
Ronal Watrianthos, Ibnu Rasyid Munthe, Rahma Muti'ah
}

\begin{abstract}
Along with the rapid development of Social Networking Sites (SNS), social media, recently, has become a lifestyle for many people around the world, including in Indonesia. The data in January 2018 showed that in Indonesia out of 132.7 million internet users, almost all (131 million), or up $23 \%$ from the data in 2017, were Facebook users with the dominance of 18-24 years old, $35 \%$ of whom were the highest active users. The rapid growth of Facebook users annually in Indonesia, especially in the age of students and college students, encourages researchers to conduct many empirical studies of Facebook use among students. There is a tendency for using Facebook continuously to create FAD effects (Facebook Addiction Disorder) among students and can affect the spirit of learning. This study also discusses what is the motivation for using Facebook and seeing the potential for FAD to occur. In this study, an online survey over 375 respondents from several students in Labuhanbatu District was conducted. To explore respondents' motives in using Facebook, respondents were given questions that were divided into the following five motives: social interaction, leisure time, entertainment, friends, and communication. While to look for potential addiction, respondents were given questions using the Bergen Facebook Addiction (BFAD) scale. In getting a connection between the motives for using Facebook and Facebook Addiction, the data was tested by analysis of variants (ANOVA) and partial tests using SPSS software. The results obtained were $65.8 \%$ of participants were at a moderate level, while $20.3 \%$ were at a low level, and only $13.9 \%$ of participants were at a high level. While the most significant motive affecting respondents in using Facebook is the motive to fill the time and motives for communicating.
\end{abstract}

Index Terms: Facebook Addiction, Facebook Motives, Social Media,

\section{INTRODUCTION}

The increasing of internet users around the world, according to the 2018 Q4 report Global Digital Statshot from the wearesocial.com page, has reached 4.176 billion people or $55 \%$ of the population penetration worldwide in October 2018[1]. This is also followed by the increasing number of active social media users who have reached 3.397 billion people or $44 \%$ of the world's population. For social media, Facebook remains ranked first with users reaching 2.234 million people worldwide. As many as $34 \%$ of users were under the age of 25 according to the report[2]. While in Indonesia, internet user data in January 2018 has reached 132.7 million people or $50 \%$ of Indonesia's population, this data is up 23\% from 2017[1]. Almost all of the 130 million people who are Facebook social media users with the age range of 18-24 years are the most users reaching 45 million people or $35 \%$ of the total users [1]. This is the age range when taking higher education as a student. The high percentage of Facebook users among college students encouraged researchers to conduct empirical studies on student motivation in socializing the media and seeing the effect of these motives on the tendency to be addicted to using Facebook (Facebook Addiction). Severin dan Taknard[3] state that there are five motive factors that are of interest in engaging through social media, namely the motives of social interaction, motives for leisure time, entertainment motives, motives for making friends, and motives for communicating. In this study, it will be observed whether these factors can encourage addictive disorders of Facebook (Facebook Addiction Disorder) and have the potential to bring negative effects on each individual, especially their influence in learning, academic achievement, and personal relationships with other students[4]. Facebook addiction disorder is a psychological disorder that can arise and often occurs in adolescents due to spending too much time playing Facebook. This disorder can result in not devoting their time properly when working, studying, or maintaining social relations with friends or family[5]. In addition to causing mood disorders and lack of confidence, FAD can also result in loss of self- control and tolerance[6]. The potential for Facebook addiction disorders and their relationship to motivation for use are the objectives of this study.

\section{RESEARCH METHOD}

\subsection{Respondents}

This research uses quantitative data as a research method. A number of questionnaires containing several questions related to this discussion will be given to the selected respondents[7]. Respondents are college students who are contacted through their respective campuses and then asked to answer surveys online through the link provided. The respondents consisted of Diploma and Bachelor students from the AMIK Labuhan Batu campus, STKIP Labuhan Batu, and STIE Labuhan Batu. The questionnaire was randomly assigned to 375 respondents from these three campuses. Of the 375 respondents, 123 of them were men $(32.8 \%)$ and 252 were women $(67.2 \%)$. While the age of respondents under 18 years is $22(5.9 \%)$, the age between 18-24 years is 341 (90.9\%), and above 24 years is $52(3.2 \%)$. It is also known that respondents have used Facebook for less than 1 year as many as 8 respondents (2.1\%), 1-2 years 17 respondents $(4.5 \%), 2-3$ years 31 respondents (8.3\%), 3-4 years 104 respondents $(27,7 \%)$, and at most respondents have used Facebook for more than 4 years, 215 respondents (57.3\%).

\subsection{Measures}

All respondents were asked to answer all questions on the online survey page. The questions in this survey are divided into three parts with a total number of questions as many as 40 questions. The first part consists of 10 questions relating to the demographics of respondents such as gender, age, duration of study, length of time using Facebook, and whether you have a Facebook account before or after becoming a student. The second part is a question designed to find out the motivations of respondents in using Facebook. This section consists of 25 questions divided into 5 groups of questions, 
namely the motives of social interaction, motives for filling time, motives of entertainment, friend motives, and motives for communicating. While the third part is 10 questions designed to find out the level of student addiction using Facebook. Each question uses a 5 -point Likert Scale, which is $1=$ Strongly Disagree, 5 = Strongly Agree[6].

\subsection{Methodology}

This study uses an online survey to collect answers and perceptions from respondents (students) when using Facebook. Before the questionnaire was distributed as a whole, the questionnaire pretest was conducted to several respondents to determine the validity and reliability of the survey. The validity of each survey content will be tested by Pearson correlation method[4]. While Cronbach alpha will be used to test the reliability of the survey until it reaches the desired value standard. A partial test is done to determine the direction and strength of the relationship between motivation to use Facebook and Facebook addiction. ANOVA and multiple regression analysis are also conducted to check whether there is a strength of motive influence with addiction[8]. Descriptive statistics and standard deviations are used to analyze the data in each section analyzed using the Statitiscal Package for Social Science (SPSS Version 20) software with an acceptable level about 5 percent.

\section{RESULT AND DISCUSSION}

\subsection{Demography of Students}

A total of 375 students were involved in this survey and gave their responds. Table 1 is an overview of the demographic profile of the respondents consisting of gender, age, duration of study, duration of using Facebook, and use of Facebook before entering lectures or afterwards. In terms of gender, $67.2 \%$ (252) respondents were male and $32.8 \%$ (123) were female. For ages, the majority of $90.9 \%$ (341) respondents were $18-24$ years old, $5.9 \%$ (22) were under 18 years of age, and $3.2 \%$ (12) were over 24 years old. While for the duration of study, 1 year is $13.9 \%$ (52), 2 years study duration is $12.9 \%$ (48), 3 years study period is $41.3 \%$ (154), 4 years study period is $21.2 \%(79)$, and $10.7 \%$ (40) for studies over 4 years. In terms of using Facebook, 2.1\% (8) only use under 1 year, $4.5 \%$ (17) use Facebook $1-2$ years, $8.3 \%$ (31) use Facebook for 2-3 years, 27.7\% (104) of respondents used Facebook for 3-4 years, and at most respondents $57.3 \%$ (215) had used Facebook for more than 4 years. The last question in this section is whether respondents have used Facebook before or after entering lectures before $2.7 \%$ (10) and after $97.3 \%$ (365).

Table 1. Students Demographic

\begin{tabular}{|c|c|c|}
\hline Demographic Profile & $n(375)$ & $\mathrm{n}(\%)$ \\
\hline \multicolumn{3}{|l|}{ Gender } \\
\hline Male & 252 & 67,2 \\
\hline Female & 123 & 32,8 \\
\hline \multicolumn{3}{|l|}{ Age } \\
\hline$<18$ years old & 22 & 5,9 \\
\hline $18-24$ years old & 341 & 90,9 \\
\hline$>24$ years old & 12 & 3,2 \\
\hline \multicolumn{3}{|l|}{ Year of Study } \\
\hline $1^{\text {st }}$ year & 52 & 13,9 \\
\hline $2^{\text {nd }}$ year & 48 & 12,9 \\
\hline $3^{\text {rd }}$ year & 154 & 41,3 \\
\hline
\end{tabular}

$$
\begin{array}{lll}
4^{\text {th }} \text { year } & 79 & 21,2 \\
>4^{\text {th }} \text { year } & 40 & 10,7
\end{array}
$$

Time Using Facebook

$\begin{array}{lll}<1 \text { year } & 8 & 2,1 \\ 1-2 \text { year } & 17 & 4,5 \\ 2-3 \text { year } & 31 & 8,3 \\ 3-4 \text { year } & 104 & 27,7 \\ >4 \text { year } & 215 & 57,3\end{array}$

Have a Facebook Account before entering the college

Yes $\quad 365 \quad 97,3$

No $\quad 10 \quad 2,7$

\subsection{Facebook Usage Motives}

Everyone will have different tastes and needs for social media whether using Facebook, Instagram, Twitter, WhatsApp, Line, and so on. The use of Facebook for students in Labuhanbatu Regency from 375 respondents showed that the interaction motif $(x 1)$ was 154 respondents or $14.18 \%$, the motive for filling time (x2) was 5 respondents or $1.33 \%$, entertainment motives $(x 3)$ were 18 respondents or $4.81 \%$, friend motives (x4) are 157 respondents or $41.98 \%$, and the motives for communicating (x5) are 40 respondents or $10.69 \%$. The five motives that become the highest are the motives of social interaction, then followed by the motives of friends. While the other three motives, namely the motive of filling time, the motive of entertainment, and the motive for communicating are not too dominant Some other studies[9] state that motives for entertainment can be more dominant motives among students in using social media. This is probably related to the selection of social media other than Facebook such as Instagram, where the content or features are related to the processing of photos and videos so that they appear more entertaining.

\subsection{Partial Test}

After doing the descriptive test, then the partial test is carried out to test whether the independent variables (variable $\mathrm{x}$ ) on the interaction motif $(x 1)$, the motive fill time (x2), entertainment motives ( $x 3)$, friend motives ( $x 4)$, and the motives for communicating (x5) partially (respectively) have an influence on the potential for Facebook addiction. The partial test results are shown in Table 2 with the decision assumption is $t_{\text {count }}>t_{\text {table }}$ and the sig value $<0.05$, then partially independent variables have a significant effect on the variable dependence. Whereas if $t_{\text {count }}<t_{\text {table }}$ and sig value $>0.05$ then partially independent variable does not have an effect and is not significant with dependent variable.

Table.2 Partial Analysis Results

\begin{tabular}{lccclll}
\hline \multicolumn{1}{l}{ Model } & \multicolumn{1}{c}{ B } & Std Error & \multicolumn{1}{c}{ Beta } & t Sig. & \\
\hline (Constant) & -1.896 & 2.1 .06 & -900 & .369 & \\
Social Interaction & & & & & \\
Motives & .044 & .109 & .020 & .402 & .688 \\
Time-filled Motive & .769 & .141 & .305 & 5.449 & .000 \\
Entertainment Motif & -.070 & .119 & -.032 & -.582 & .561 \\
$\begin{array}{l}\text { Friend Motif } \\
\text { Communication }\end{array}$ & .113 & .133 & .048 & .852 & .395 \\
Motive & .793 & .128 & .350 & 6196 & .000 \\
\hline
\end{tabular}

From the table above the results show that the motive for filling time has a value of $t_{\text {hit }} 5.449>t_{\text {tab }} 1.64$ and the motive for communicating with a value of $t_{\text {hit }} 6.196>t_{\text {tab }} .64$ with a sig value of $0.000<0.05$, so it can be concluded that motives fill time and motives of communication have influence significant 
effect on Facebook's addiction potential. This means that for students in Labuhan Regency, the motive is to fill the time and the motives for communicating are more influential towards the tendency of addiction to use Facebook. The more free time a person has, the higher the level of tendency or potential for someone to experience Facebook addiction, so also the more someone has a little chance to communicate with others, the higher the potential for someone to be addicted to using Facebook. Whereas the partial test results for social interaction motives $\left(t_{\text {hit }} 0.402<t_{\text {tab }} 1.64\right)$, entertainment motives $\left(\mathrm{t}_{\text {hit }}-0.582<\mathrm{t}_{\text {tab }} 1,64\right)$, and friend motives ( $\left.\mathrm{t}_{\text {hit }} 0.852<\mathrm{t}_{\text {tab }} 1,64\right)$ have no influence on Facebook's addiction potential for students in Labuhanbatu Regency. Although different from the results of other studies[10] conducted on students of the Malaysia Science University, results were obtained that friends motives, entertainment motives, and motives for seeking information became motives that influence the level of frequency or tendency to use Facebook.

\subsection{Variant Test Analysis and Determinant Coefficient}

Variant test results ( $F$ test) are used to see the effect of all independent variables on the dependent variable. This is seen by comparing the value of $F_{\text {hit }}>F_{\text {tab }}$ and the value of sig $<0.005$.

\section{Table.3 Hasil Uji Varian (Uji F)}

\begin{tabular}{lcccc}
\hline Model & Sum of Squares df & Mean Square & F & Sig. \\
\hline Regressio & 7988.457 & 5 & 1597 & $38.103 .000^{\mathrm{b}}$ \\
Residual & 15430.401 & 368 & 41.930 & \\
Total & 23418.858 & 373 & & \\
\hline
\end{tabular}

From the results shown in Table 3 , it is obtained that the results of the $F$ Variant Test are 38,103 with a significant level of 0,000 with a $F_{\text {table }}$ value of 2.23. Due to the value of $F_{\text {count }}$ $38.103>\mathrm{F}$ it can be concluded that simultaneously all motive variables influence and significantly influence Facebook's addiction potential. While to see the magnitude of the influence of independent variables on the dependent variable can be seen from the R2 test value and to see the strength of the relationship can be seen from the value of $R_{\text {hit. }}$. The calculation results can be seen in the table below:

Tabel.4 Determinant Coefficient Test Results (R2 Test)

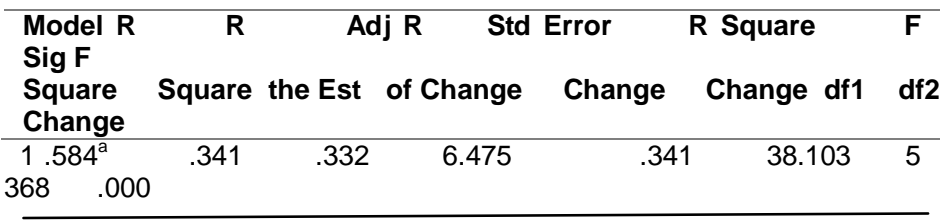

From the results of the above calculations, it can be obtained an $R$ value of 0.584 or equal to $58.4 \%$ which indicates that the relationship between variables on all motives with Facebook's addiction potential is quite tight. While the determinant coefficient value of 0.341 or equal to $34.10 \%$ confirms that the motive variable as a whole influences facebook addiction potential for students in Labuhanbatu Regency by $34.10 \%$ with motives that influence the motive for filling leisure time and communicating motives while $63.89 \%$ is influenced by other factors besides motives that influence addiction such as a person's personal characteristics, peers' environment, frequency of activities, desires or interests and direction of attitudes towards facebook itself.

\section{CONCLUSION}

No doubt Facebook has become a part of the lives of students, especially in Indonesia. Based on this study, of the 375 respondents surveyed, $97.3 \%$ said they already had a Facebook account before entering the lecture and $57.3 \%$ had used it for more than 4 years. Among the five motives tested, the motives for filling time and communicating motives were the most influential and significant motives when partially tested compared to the motives of social interaction, entertainment motives, and motives of friends towards the tendency or potential addiction to using Facebook. But overall the motive variables affect the potential of Facebook addiction with the amount of influence on students in Labuhanbatu Regency by $34.10 \%$ with motives that influence the motives to fill free time and motives of communication while $63.89 \%$ are influenced by factors other than motives that influence addiction such as one's personal characteristics, peer environment, frequency of activities, desires or interests and direction of attitude towards Facebook itself. Based on this study also obtained results that the potential for Facebook addiction disorders of students in Labuhanbatu Regency was at a moderate level with a percentage of $65.8 \%$ in 375 respondents. While $20.3 \%$ were at a low level and $13.9 \%$ at a high level. Even though it is still in the category that is not worrying about $13.9 \%$, it should be a concern to reduce the level of potential addiction to Facebook use among Labuhanbatu Regency students, this is because if it is overlooked then the potential of this potential becomes a disorder (addiction) using Facebook that will give negative impacts such as not caring about the surroundings, lack of socializing with the environment, wasting money on less useful things, disrupting health, reduced study time and other maladaptive behaviors.

\section{REFERENCES}

[1]. We Are Social, "Indonesia Digital Landscape," 2018.

[2]. We Are Social Ltd. and Hootsuite Inc., "2018 Q4 Global Digital Statshot," 2018.

[3]. W. J. Severin and J. W. Tankard, Communication Theories: Origins, Methods, and Uses in the Mass Media, Fifth Edit. 2010.

[4]. SHARIFAH SOFIAH, SITI ZOBIDAH OMAR, J. BOLONG, and $M$. N. OSMAN, "FACEBOOK ADDICTION AMONG FEMALE UNIVERSITY STUDENTS," Rev. Adm. Publica Si Polit. Soc., vol. 41, no. 21, pp. 3227-3242, 2014.

[5]. Christy M.K.Cheung and D. R.Thada, "The impact of electronic word-of-mouth communication: A literature analysis and integrative model," Decis. Support Syst., vol. 54, no. 1, pp. 461-470, 2012.

[6]. Z. Zaremohzzabieh, B. A. Samah, S. Z. Omar, J. Bolong, N. Akhtar, and N. A. Kamarudin, "Addictive Facebook use among university students," Asian Soc. Sci., vol. 10, no. 6, pp. 107-116, 2014.

[7]. Erlin, Susandri, and Triyani Arita Fitri Informatics, "We are Different but Alike: A Comparative Analysis between Students' and Teachers' Use of Facebook," 
J. Phys. Conf. Ser. PA, vol. 9, no. 11, pp. 63-70, 2016.

[8]. J. Khumsri, "Prevalence of Facebook Addiction and Related Factors Among Thai High School Students," vol. 98, no. 5, pp. 51-61, 2015.

[9]. M. F. Syahreza and I. S. Tanjung, "Motif Dan Pola Penggunaan Media Sosial Program Studi Pendidikan Ekonomi Unimed," vol. 2, pp. 61-84, 2018.

[10]. Mohd Zaidi Mahmud and B. Omar, "Motif dan Kekerapan Penggunaan Facebook Dalam Kalangan Pelajar Universiti," J. Komun., vol. 29, no. 1, pp. 3554, 2013. 